\title{
Development of Electronic Educational Resources Focused on the Formation of Trilingual Competence
}

\author{
Yelena Chzhan, Marina Karachevtseva, Galina Danilova \\ D. Serikbayev East-Kazakhstan State Technical University, Ust-Kamenogorsk, Kazakhstan
}

\begin{abstract}
The processes of globalization and informatization of the society make it necessary and possible to improve language teaching by using information technologies, which are recognized as the effective means of teaching languages, and provide a variation of forms and methods of training, flexibility of approaches to the development of its content and, as a consequence, high quality of knowledge. In the Republic of Kazakhstan, the focus is on multicultural and multilingual education. Thus, topical issue is the creating of effective e-learning resources (ELR), allowing students to develop a trilingual competence. For successful implementation of learning and cognitive activity into professional, the multimedia complex “English for IT-specialists” has been designed. It is focused on the new historical conditions and needs, as it is aimed at the development of trilingual competence that ensures equal access to knowledge in the field of vocational English of both students speaking the state language (Kazakh), and the Russian language. It may be used in the classroom, for students' independent work, and for distance learning as well.
\end{abstract}

Keywords: professional activity, electronic educational resource, trilingual competence, multimedia complex

\section{Introduction}

Changes taking place in modern society, namely, globalization trends, global integration in various fields of economic, technical, cultural, social, and individual life require training competitive professionals. The competitive specialist today is not only a specialist with professional competence, but a multilingual and multicultural personality, possessing specific language (linguistic) competences. Therefore, in the present time in the Republic of Kazakhstan, the process of active use of the three languages is taking place: "Kazakh language — as the state language, Russian—as the language of international communication, and English—as the language of successful integration into the global economy” (Nazarbayev, 2011).

In addition, the development of modern society is characterized by a strong influence of computer technology, which penetrates in all spheres of human activity, and provides flows of information in the society, forming a global information space. An integral and essential part of these processes is the computerization of

\footnotetext{
Yelena Chzhan, associate professor, Ph.D., Department of Information Technology and Energetics, D. Serikbayev East-Kazakhstan State Technical University.

Marina Karachevtseva, senior researcher, Department of Information Technology and Energetics, D. Serikbaev East-Kazakhstan State Technical University, Kazakhstan.

Galina Danilova, researcher, Department of Information Technology and Energetics, D. Serikbaev East-Kazakhstan State Technical University, Kazakhstan.
} 
education. At the present stage in Kazakhstan, a new educational system is being formed, which is based on the use of elements of e-learning. The current situation makes it necessary to improve organizational forms and find the most effective means of teaching languages. Due to informatization of the society, information technologies (multimedia, networking, communications) are recognized as the effective means of language teaching, which is proven by many psychological and educational researches. They provide a variation of forms and methods of training, flexibility of approaches to the development of its content and, as a consequence, high quality of knowledge (Alexandrov, 2009; Polat, 2002; Ruzhentseva, 2005; Shamov, 2001).

\section{Justification for the Relevance of Creating the Multimedia Complex, Aimed at Developing a Trilingual Competence}

Market analysis of multimedia programs showed that there is a sufficient variety of quality multimedia training programs for language education, but they do not involve the developing of a trilingual linguistic competence, as required by a new model of education in our Republic, which focuses on multicultural and multilingual education. Thus, topical issue is the creating of effective e-learning resources (ELR), allowing students to develop a trilingual competence.

A new social order for professionals who speak three languages was the reason to participate in the grant project "Developing trilingual competence in college IT-students by means of multimedia”, which is carried out on the basis of D. Serikbaev East-Kazakhstan State Technical University by the team of teachers of language and IT-disciplines. As a result of the project, the multimedia complex "English for IT-specialists" has been designed.

\section{Description of the Multimedia Complex}

The multimedia complex "English for IT-specialists" is focused on the new historical conditions and needs, as it is aimed at the development of trilingual competence that ensures equal access to knowledge in the field of vocational English of both students speaking the state language (Kazakh) and the Russian language. It may be used in the classroom, for students' independent work, and for distance learning as well.

\section{Targets}

The goals of creating the complex: (1) developing college IT-students' trilingual linguistic competence, (2) improving the quality of education through the use of interactive teaching methods and tools, (3) developing students' cognitive and creative abilities, (4) increasing motivation to learning languages, and (5) encouraging students' independent work with instructional materials and reference books.

\section{Architecture}

To implement the multimedia complex, Flash technology, which "combines many powerful technological solutions in the field of multimedia presentation” was chosen (Lott, 2007).

This technology is a good choice for creating ELR for a variety of reasons, among which are the following: (1) All basic elements of multimedia are implemented: images, text, movement, sound and video, interactivity, without resorting to additional programs; (2) it provides compactness: The size of the resulting program is minimal and the result of their work does not depend on users' screen resolution; (3) Flash Player is very prevalent and is freely available; and (4) if necessary, the contents can be published as stand-alone executable applications that allows to distribute it, without requiring Flash Player on users' computers. 
The chosen technology allows to realize all requirements to multimedia complexes.

Apart from the above, while developing the multimedia, other requirements for software complexes of this type were also respected, namely: (1) ability to organize and browse through the Internet; volume of information of each module is about $9 \mathrm{MB}$, so getting it on the network request is not a fundamental difficulty even for low-flow computer networks; (2) ease to use; (3) easy navigation system, allowing to quickly navigate through the material of the module; and (4) ergonomic design.

Multimedia complex "English for IT-specialists" is an electronic educational resource of modular architecture.

Each training module is an autonomous, complete multimedia product with its content, theme, and functions that solves certain educational goals and objectives.

Six modules make a complete e-course-They have a unified architecture and standardized internal parameters. The modules are interconnected by learning logic, and each has its theme, grammatical and lexical material to study.

Each module consists of four sections: Language, Grammar, Reading and Speaking, Test. The modules include interactive, rich media content with a nonlinear navigation. Interactive content is understood as electronic content, where operations with its elements are possible.

All operations are performed in the active content field (see Figure 1).

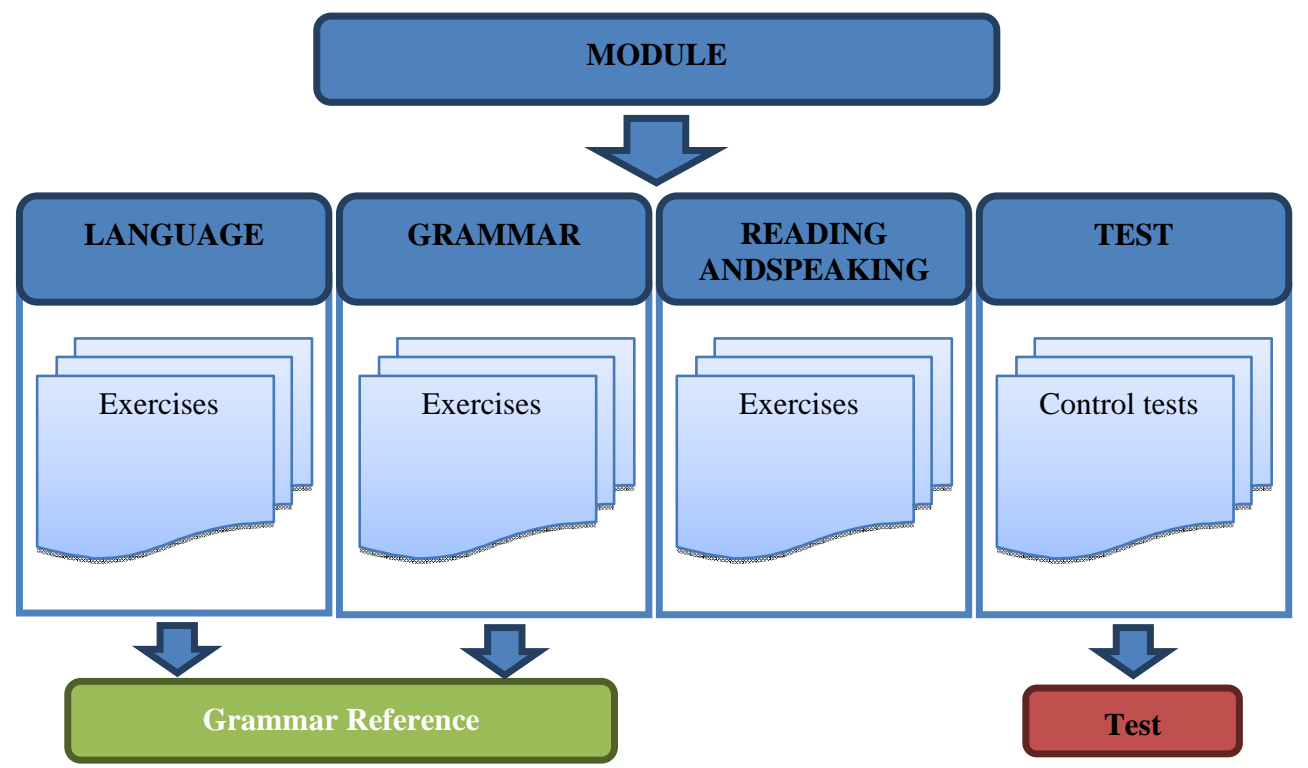

Figure 1. Module structure.

The requirements for interactivity are particularly important, as interactivity provides expansion of the sector of independent academic work through the use of active learning forms.

Different types of interactive exercises are presented in the multimedia complex: (1) tasks with answer choices (students select the correct answer (answers) of the number of options); (2) supplement tasks (students formulate short or complete responses); (3) tasks to establish correspondence between the elements of two sets; (4) tasks to establish the correct sequence, logical connections among the proposed elements; and (5) tasks for intensive remembering keywords. 


\section{Methodological Basis of the Language Content}

The bases for the development of the language part of the complex were

(1) philosophical and pedagogical theories on learner-centered teaching by Yakimanskaya (2002), subject -subject relations of the teacher and learners by Vygotskyi (2005), Leontiev (1994), Platonov (1986);

(2) linguistic ideas about the relationship of language, speech, and speech activities;

(3) lingua-didactic theories of communicative and competence-based approaches in language teaching (Bermus, 2005; Verbitsky, 2004), in combined teaching of a bilingual and multilingual individual to a foreign language with basic first language and the language of mediation;

(4) theoretical principles of modular design technology (Polat, 2002), noosphere technology (Maslova, 2002), and multi-level technology of language training; and

(5) the doctrine of the holistic approach to the process of perception, processing, storage, and realization of speech in the society.

The major component of the complex is the use of the competence-based approach that fosters students' foreign language communicative competence. Transformation of learning and cognitive activity into professional is implemented by using the contextual approach.

Furthermore, the profession-oriented approach is also implemented, as teaching a foreign language is an integral part of the process of formation of professional competence of the future specialist.

Using the profession-oriented approach helps students master the skills and abilities of foreign language communication for purely professional purposes (Obraztsov, 2005).

Communicative approach is also taken into account, as the main task of teaching a foreign language at the present stage is the development of foreign language communicative competence, which is regarded as a certain level of language, speech, compensatory, socio-cultural competencies that allow learners to reasonably vary their verbal behavior depending on functional factors of foreign language communication (Passov, 1991).

Learning process involves the insertion of the learner-centered approach that allows to reveal and use the subjective experience of each student, his personal and psychological characteristics, causing the effectiveness of training activities, their interaction with each other and with the teacher (Shamov, 2001).

To implement the above approaches in teaching professional English, the complex is based on the use of the most effective teaching methods: lingua-cultural, communicative, situational, role-playing, project, audio-lingual (Galskova, 2000; Polat, Bukharkina, Moiseyeva, \& Petrov, 2008; Ruzhentseva, 2005).

The main principles of selection and design of learning tasks are: (1) professional and communicative orientation, (2) individualization, (3) activity, (4) rational combination of training and creative activity of learners, (5) system and consistency in the presentation of educational material, (6) novelty, and (7) scientific character.

Implementation of the principle of integration of foreign language into training and professional activity is dictated by the need to create a multicultural environment in the learning process.

Interactive learning with computer-based training programs helps to implement a set of these principles more completely.

\section{Description of the Language Content}

Teaching any language is based on analogy with the native language. Therefore, the formation of speech 
competence occurs through integration of English, Kazakh, and Russian. Since the foundation of the complex is professional English language training, its content is based on English grammar and implies a three-level mastery of the English language. Mastering the Kazakh language assumes the basic level. Accordingly, the content includes grammatical models of the Kazakh language, sufficient for the formation of communicative competence of the basic level. In this context, the phenomenon of transposition is taken into consideration (positive transposition of identical language universals_similarities in the construction of words, sentences, etc.). All ideas about the language and the features of its use are generated synchronously (simultaneously).

Linguistic features of different languages were also considered as the basis of exercises. For this, a set of techniques associated with drawing comparisons was used (in the English, Kazakh, and Russian languages). These techniques are implemented through specific models of language activities and are filled with trilingual content.

Since the complex is designed to train IT-specialists, its themes correspond to the specificity of the profession and lexical material involves mastering professional-directed vocabulary. Glossary compiled in the English, Kazakh, and Russian languages; professional terminology in English, Kazakh, and Russian; exercises based on the similarities of the Kazakh and English grammar; cross-cultural material allowing to acquaint learners with cultural information including speech etiquette, features of verbal behavior in the course of communication, customs and traditions of both the native country, and the country of the foreign language-All this helps to create a multicultural environment in the classroom and the formation of a trilingual language competence.

However, knowing a foreign language is not enough, it is necessary to integrate language and professional skills. For successful implementation of learning and cognitive activity into professional, the model of professional activities of the competitive specialist is taken as a focus in the complex.

With regard to intra-subject links, they are expressed in combined teaching to all four language skills: speaking, listening, reading, writing, and each of them can act as a goal and as a means of teaching English; there are three levels, each is aimed at developing, improving the knowledge and skills obtained by learners at the previous level, and the base for the next step, together constituting a single course of discipline "Professional English".

\section{Conclusion}

We believe that the use of the multimedia complex in learning process allows

(1) to develop a trilingual linguistic competence;

(2) to implement the learner-centered approach to teaching. Thanks to the interactive computer program, learners have the ability to manage the process of learning the language. Individualization is reflected in self-selecting the material complexity (level) and the sequence of exercises. Online mode also allows learners to take control of the rate of studies; branched structure of hyperlinks makes it possible to receive information from the glossary and grammar handbook;

(3) to develop system thinking, learn to analyze, collate, and summarize the facts;

(4) to be aware of linguistic phenomena, develop linguistic abilities, create communicative situations, and automate language and speech actions;

(5) to ensure learners' independent work intensification. They cannot only learn the material on their own, 
but also test themselves using built-in test systems which provide instant control of gained knowledge;

(6) to increase practical orientation of learning process, and motivate students to develop their intellectual, creative abilities and abilities to acquire new knowledge, as the tasks included in the multimedia complex, involve seeking additional information necessary to perform a particular exercise. In addition, the tasks imply the creation of booklets, computer presentations, videos or movies using computer programs (PowerPoint and others);

(7) to train different types of language skills and combine them (monologue and dialogue speech, listening, writing, reading);

(8) to organize classes using colorfully decorated teaching aids, such as text, graphics, drawing with animation, audio, video. Perception of educational materials is activated through eyesight (text, color, still images, video, animation) and hearing (actor's or presenter's voice, music, or noise in the background), that creates a predetermined emotional background, which increases the efficiency of learning process and meets the principles of didactics — using audio and visual aids;

(9) to create a favorable social and psychological atmosphere in the classroom, as learners can evaluate their knowledge through self-control, avoiding censure, being able to choose for themselves the level of training that gives them confidence;

(10) to add new material to the main part: vocabulary, types of exercises; and

(11) to create subject-subject learner-teacher interaction in the classroom, mediated through interactive computer programs and audiovisual media.

\section{References}

Alexandrov, K. V. (2009). Multimedia complex as a means of learning lexical side of foreign speech of linguistic university students (on the example of German language) [Abstract]. N.A.Dobrolyubov Nizhny Novgorod State Linguistic University, Nizhnyi Novgorod, 16.

Bermus, A. G. (2005). Problems and prospects of implementation of competence-based approach in education. Eidos, (4). Retrieved from http://www.eidos.ru/journal/2005/0910-12.htm

Galskova, N. D. (2000). Modern methods of teaching foreign languages. Moscow: Arkti.

Leontiev, A. N. (1994). Philosophy of psychology (pp. 142-228). Moscow: Moscow University Publishing House.

Lott, J. (2007). Collection of recipes (p. 554). St. Petersburg: Piter, Russkaya redaktsiya.

Maslova, N. V. (2002). Noospheric education (p. 15). Moscow: "Noosfera” Publishing House.

Nazarbayev, N. A. (2011). Message of the President of the Republic of Kazakhstan to the people of Kazakhstan. Astana: Elorda.

Obraztsov, P. I. (Ed.). (2005). Professionally-oriented language training for language faculties of universities: Textbook (p. 287). Oryol: Oryol State University.

Passov, E. I. (1991). Communicative approach to foreign language speaking. Moscow: Prosveshenie.

Platonov, K. K. (1986). Structure and development of personality (p. 254). Moscow: Nauka.

Polat, E. S. (2002). New teaching and information technology in the education system. Textbook for students of pedagogical universities and further teachers' training (p. 272). Moscow: Academy.

Polat, E. S., Bukharkina, M. Y., Moiseyeva, M. V., \& Petrov, A. Y. (2008). New teaching and information technology in education: Textbook for university students (3rd ed., p. 272). Moscow: Publishing Center “Academy”.

Ruzhentseva, T. S. (2005). Using of new technologies in teaching English to students of information technology [Abstract]. Peoples' Friendship University of Russia, Moscow, 17.

Shamov, A. N. (2001). Using of information technology in learning a foreign language (p. 125). Moscow: Vysshaya Shkola.

Verbitskyi, A. A. (2004). Competence approach and the theory of contextual learning: Proceedings of the fourth meeting of methodological seminar of November 16 (p. 84). Moscow: Research Center of quality training problems.

Vygotskyi, L. S. (2005). Psychology of human development (pp. 209-1136). Moscow: Eksmo.

Yakimanskaya, I. S. (2002). Learner-oriented education in the modern school (p. 96). Moscow: Sentyabr. 